\title{
Study on the Correlation between Consumer Ethnocentrism and Demographic Factors in China
}

\author{
Sui Hongxia \\ Economy and Management College \\ Weifang University \\ Weifang, China \\ wfshxgjmy@163.com
}

Based on a Broader Samples Including Rural Population

\begin{abstract}
Many scholars examined CE measured with CESCALE among different countries and their antecedents and consequences, but the prior researches neglected the people living in countryside which restricted applicability of their research findings. This paper focuses on researching the correlation between consumer ethnocentrism level of Chinese people and the demographic segmentation variables adopting samples from the whole Shandong province including the people living in cities and countryside. The paper put forward five hypotheses and tested them accordingly. Two independent samples test and One-way ANOVA technique were applied. Hypothesis1 tested the reliability and validity of CESCALE and found it was valid and reliable to use the CETSCALE to make further analysis. Hypothesis2 through Hypothesis5 tested the correlations between consumer ethnocentrism and gender, age, income and educational level respectively and the findings revealed that gender and income had no correlation with $\mathrm{CE}$, age had positive correlation with $\mathrm{CE}$ and educational level had negative correlation with $\mathrm{CE}$ in China. But on the variables of age and educational level, the people in some groups did have differences, but the differences were not significant. International marketers should be cautious on deciding segmentation variables and application of these variables.
\end{abstract}

Keywords-consumer ethnocentrism; demographic factors; CETSCALE; rural samples; market segmentation

\section{INTRODUCTION}

With the development of global economic integration, more and more countries open their markets, gradually loosen trade regulations and warmly welcome foreign investments which provide valuable opportunities for multinational corporations and consumers have greater and easier access to imported goods than ever before. Consequently, the global business competition is becoming more and more fierce and consumers also diverse in needs and wants.

In order to enhance market competition ability and improve customer satisfaction, international marketers are trying to focus on more specific market segments, such as $P \& G$, Unilever etc. Thus, the exact market segmentation is absolutely vital for business success and market gain ${ }^{[1]}$. Market segmentation attempts to isolate the traits that distinguish a certain group of consumers from the overall market. Demographic segmentation variables are amongst the most popular bases for segmenting customer groups.
An understanding of the group's characteristics, such as age, gender, geographic location, income and buying patterns plays a vital role in the developing a successful marketing strategy ${ }^{[2]}$.

International marketers are facing many great challenges in the global environment, especially in the post economic and financial crisis era, one of which is consumer ethnocentrism. Even products are superior in quality or lower in price to those of the host countries, doing business successfully in foreign markets might not be easy for several non-regulatory reasons ${ }^{[3]}$. In order to strengthen and expand market share, international marketers have to evaluate the level of consumer ethnocentrism across countries, across the segments within each country or even across the similar sub-groups in different countries.

CETSCALE was commonly used to measure consumer ethnocentrism level and lots of scholars had testified the validity of CETSCALE and applied it in research. The mean scores on the CETSCALE appear to be stable over time when the population is viewed as a whole but they are not stable for specific sub-groups ${ }^{[4]}$.

Although consumer ethnocentrism has been well studied in the literature, consumer ethnocentrism in Chinese cultures has not been examined exclusively using consumer survey data from different sub-cultural societies to reveal distinct patterns of ethnocentrism ${ }^{[5]}$.

The prior researches have two limitations on sampling which restricted applicability of their research findings. One is most researches mainly sampled in big cities and almost no rural people were included in the samples and another one is most surveys did among college students which elicit to insufficient representativeness of the samples. With the development of Chinese economy, more and more people living in the countryside, especially those living in the east coast, are entering into the middle income class and their buying power is improving greatly and they also can afford imported goods and services. This paper focuses on researching the correlation between the consumer ethnocentrism level of Chinese people and the demographic segmentation variables adopting samples from a broader region, the whole Shandong province including rural population, instead of one city or couples of cities. Such broader sampling ensured representativeness of the findings and formed the uniqueness of this study. 
Shandong province is located in the east coast and is one of the most development provinces of China. Such samples choosing based on the following thoughts that: even the general consumer ethnocentrism level is high or low in a country, different sub-groups may have different consumer ethnocentrism levels; the people from Shandong province have good income and they can represent most of the east wealthy provinces in this country and thus these east regions have been the main target markets of MNC, so such research conclusion will provide more reliable and useful implications to international marketers.

The studying of consumer ethnocentrism would be useful for multinational marketers to devise product segmentation and positioning strategies for both domestic and imported goods and enhance the effectiveness of marketing communications in China.

\section{CONSUMER ETHNOCENTRISM AND INTERNATIONAL RESEARCH}

\section{A. Ethnocentrism}

The origin of the concept of ethnocentrism was attributed to Summer who explained it as a feeling of superiority for one's group and all things related to the group. Over the years, the concept has added psychological and now even economic overtones ${ }^{[6]}$.

Shimp and Sharma believed ethnocentrism represents the tendency for individuals to view their own group as omnipotent, to view other groups from their own perspective, and to reject culturally dissimilar ideas while blindly accepting culturally similar ideas and people ${ }^{[7]}$. In essence, highly ethnocentric people take pride in their own values, symbols, and hold in contempt the objects and values of other groups ${ }^{[8]}$. Ethnocentrism means culturallybiased judgment ${ }^{[6]}$.

\section{B. Consumer Ethnocentrism and CETSCALE Reference}

Consumer ethnocentrism (CE) is one specific behavior associated with the broader concept of ethnocentrism. Shimp and Sharma defined consumer ethnocentrism as "the beliefs held by American consumers about the appropriateness, indeed morality, of purchasing foreign made products",[7]. They believe that people who are highly consumer ethnocentric feel that purchasing foreign products is wrong because it hurts the domestic economy, results in loss of jobs, and is unpatriotic. They also feel a sense of belonging to their consumer ethnocentric in group, which results in an understanding of what purchase behaviors are acceptable or unacceptable to the in-group. In contrast, the non-ethnocentric individual evaluates products more objectively, regardless of country of origin.

Based on the above understanding on CE, Shimp and Sharma developed consumer ethnocentrism test scale (CETSCALE) consisted of 17 items. Also, they validated that the CETSCALE was reliable and valid ${ }^{[7]}$. However, the CETSCALE was developed and validated with samples of American consumers only. Later, Netemeyer, Durvasula, and Lichtenstein assessed the psychometric properties and nomological validity of the CETSCALE across four different countries and got results that the CETSCALE was a reliable measure across the four countries and afford some evidence of validity as well ${ }^{[8]}$. Teo, Mohamad and Ramayah looked at the CETSCALE and wrote that it had high validity in many countries and had been accepted and used frequently to understand $\mathrm{CE}$ throughout the world ${ }^{[9]}$.

\section{THE HYPOTHESIS}

The intent of the research was to detect the relativity between Chinese people's CE level and the demographic segmentation variables adopting samples from a wider region. As the literature did not supply ample rationale for using CE scale in China, so it was necessary to replicate the CETSCALE reliability firstly and then apply the exploratory factor analysis to evaluate the effectiveness of the CE scale. Specifically, we hypothesize the following:

$\mathrm{H} 1$ : The internal consistency reliability for the $\mathrm{CE}$ is high and the effectiveness of CE scale is high.

Shimp ${ }^{[10]}$ and Good and Huddleston ${ }^{[1]}$ have said that consumer demographics such as income or education level has a significant influence on consumer ethnocentrism.

Klein and Ettenson utilized a national representative survey of US citizens to examine consumer ethnocentrism and found that females and consumers of lower socioeconomic status were more ethnocentric ${ }^{[12]}$. Philp and Brown concluded that respondents with high consumer ethnocentrism levels who favored domestic products were women who came from lower socioeconomic groups, were less educated and had limited cultural exposure ${ }^{[13]}$.

Bandyopadhyay and Munir Muhammad studied consumer ethnocentrism in India and Bangladesh, and argued that there was no significant correlation between ethnocentrism and age in either sample ${ }^{[14]}$. Imbert et al. concluded that age and gender were not strong predictors of consumer ethnocentrism in Russia ${ }^{[15]}$.

Hsu and Nien examined consumer ethnocentrism in Taipei and Shanghai, China, and concluded that Ethnocentric consumers in both cities were relatively older, with lower educational levels ${ }^{[5]}$. Bandopadhyay and Saevarsdottir argued that although ethnocentrism had a significant positive correlation with age, there were no significant difference on the level of ethnocentrism between men and women in Iceland ${ }^{[16]}$.

From the reviewing the literature, we can find the conclusions on the correlation between ethnocentrism and demographics are not totally coincident, some even contradictory because of different sampling methods and different research periods. Based on the previous literature, it was expected the following hypotheses:

$\mathrm{H} 2$ : Female respondents are more ethnocentrism than male respondents.

H3: Ethnocentrism have a significant correlation with age, the older respondents are more ethnocentrism than the young respondents.

H4: Ethnocentrism have a significant correlation with income, and the low-income respondents are more ethnocentrism than the high-income respondents.

H5: Ehnocentrism have a significant correlation with education, and the respondents at lower educational levels are more ethnocentrism.

\section{METHODOLOGY}

Convenience samples of the people living in Shandong province were selected and administered the 17-item CETSCALE developed by Shrimp and Sharma and dada 
pertaining to demographics including gender, age, income and education were also obtained.

The original study CETSCALE was developed in English and was translated into Mandarin by using parallel translation method. The people were invited to complete the CETSCALE which consists of 17 items and all items were measured on a 7-point Likert-type scale ranging from $7=$ strongly agree to $1=$ strongly disagree. The higher value means the more ethnocentric while the lower value means the less ethnocentric.

More than 100 freshman and sophomore studying in the Economy and Management school of Wei fang University, whose hometown is in Shandong province, participated in the data collecting. Such arrangement on the thoughts that: the students came from different regions of Shandong including cities and countryside and they could get more representative dada; freshman and sophomore are more serious and responsible and would like to help their teacher to do survey. The specific dada collecting involved the following steps: the author gave simple training on the questionnaire and data collecting to the students before the Winter holiday; the survey was done during the Spring holiday; the samples were the students relatives, classmates or neighbors; Every participant was informed that the purpose for conducting the study was to investigate consumer ethnocentrism, the survey was voluntary and it would take 5-10 minutes to complete and the information was completely confidential and anonymous; the questionnaires were handed in at the beginning of the new spring semester. There were 289 people accepted the survey and 243 questionnaires were valid.

After collecting the questionnaires, scrutiny was given and the unfit ones were rejected, then all data on the qualified 243 questionnaires were put in SPSS by the author and hypothesis1 through hypothesis6 were tested one by one.

\section{RESULTS}

The Cronbach's Alpha of all samples was 0.916 which was higher than 0.9. Nunnaly indicated 0.7 was an acceptable coefficient ${ }^{[17]}$. Thus this test result showed that the internal consistency reliability of CETSCALE was high. The Kaiser-Meyer-Olkin Measure of Sampling Adequacy was 0.895 and the Bartlett's Test of Sphericity result is 0.000 which indicated that the scale's validity is high. Thus the hypothesis1 was accepted and it was reliable to use the CETSCALE to make further analysis.

The mean scores for male and female are 3.9497 and 3.8042 respectively. Through independent mean t-test, at $5 \%$ significant level, the two tailed $\mathrm{P}$-value $=0.280$ was 0.001(see TABLE I). This result indicated male respondents showed little higher mean, but the difference was not statistically significant. So different gender respondents have similar $\mathrm{CE}$ level and $\mathrm{H} 2$ was refused.

TABLE I. GROUP STATISTICS ON GENDER

\begin{tabular}{|c|c|c|c|c|c|}
\hline Gender & N & Mean & $\begin{array}{c}\text { Std. } \\
\text { Deviation }\end{array}$ & $\begin{array}{c}\text { Std. Error } \\
\text { Mean }\end{array}$ & $\begin{array}{c}\text { Two Tailed } \\
\text { P-value* }\end{array}$ \\
\hline male & 116 & 3.9497 & 1.00511 & 0.09332 & 0.280 \\
female & 127 & 3.8042 & 1.08911 & 0.09664 &. \\
\hline
\end{tabular}

* The P-values were calculated through independent mean t-test, at 5\% significant level.
To test hypothesis3, One-way ANOVA was applied and we got the means of different age groups (see table II). This primitive result showed the older the respondents were, the more ethnocentrism they were.

To check whether the differences were significant, we looked at the One-way ANOVA table and got the combined P-value was 0.000 which showed, at $5 \%$ significant level, the means of different subgroups were not statistically the same. But we couldn't make sure each group was total different, so Multiple Comparisons was necessary. The P-value $=0.008$ in the test of Homogeneity of Variances depicted it was the Tamhane test result should be applied and analyzed. The Tamhane Multiple Comparisons result showed that age group1 had significant difference with the other three age groups, but group2, group3 and group4 had no significant differences among them (see table III). At last, the result indicated that ethnocentrism had a significant correlation with age, the respondents older than 35 years old are more ethnocentrism than the respondents who are younger than 35 years old. So Hypothesis3 was accepted. But the respondents who are older than 35 years old are similar ethnocentrism no matter they are younger or older.

TABLE II. HomogeneOUS SUBSETS

\begin{tabular}{|c|c|c|c|c|c|}
\hline & Group & age & N & \multicolumn{2}{|c|}{$\begin{array}{c}\text { Subset for alpha }= \\
\mathbf{0 . 0 5}\end{array}$} \\
\cline { 5 - 6 } & & & & $\mathbf{1}$ & $\mathbf{2}$ \\
\hline & 1 & $18-35$ & 102 & 3.4357 & \\
& 2 & $36-46$ & 70 & & 4.1191 \\
Student-Newman- & 3 & $46-60$ & 60 & & 4.2553 \\
Keuls & 4 & 0ver 60 & 11 & & 4.2900 \\
& & Sig. & & 1.000 & .778 \\
\hline
\end{tabular}

TABLE III. TAMHANE Multiple COMPARISONS ON AGE

\begin{tabular}{|c|c|c|c|c|c|}
\hline & (I) Age & $\begin{array}{l}(J) \\
\text { Age }\end{array}$ & $\begin{array}{c}\text { Mean Difference } \\
\text { (I-J) }\end{array}$ & Std. Error & Sig. \\
\hline Tamhane & 2 & $\begin{array}{l}2 \\
3 \\
4 \\
1 \\
3 \\
4 \\
1 \\
2 \\
4 \\
1 \\
2 \\
3 \\
\end{array}$ & $\begin{array}{c}-.81965^{*} \\
-.68346^{*} \\
-.85431^{*} \\
.81965^{*} \\
.13619 \\
-.03467 \\
.68346^{*} \\
-.13619 \\
-.17086 \\
.85431 * \\
.03467 \\
.17086 \\
\end{array}$ & $\begin{array}{l}.16699 \\
.15366 \\
.23751 \\
.16699 \\
.19142 \\
.26352 \\
.15366 \\
.19142 \\
.25528 \\
.23751 \\
.26352 \\
.25528 \\
\end{array}$ & $\begin{array}{c}.000 \\
.000 \\
.019 \\
.000 \\
.980 \\
1.000 \\
.000 \\
.980 \\
.987 \\
.019 \\
1.000 \\
.987 \\
\end{array}$ \\
\hline
\end{tabular}

Similar, we applied One-way ANOVA to test the means of different income groups and the results were showed in Table IV. At 5\% significant level, the P-value= 0.566 which depicted that the differences among the means of different subgroups were not statistically significant. This result showed that ethnocentrism had no correlation with income, no matter how high their incomes were, they had similar ethnocentrism. Then hypothesis4 was rejected. 
TABLE IV. HomogeneOUS SUBSETS

\begin{tabular}{|c|c|c|c|c|}
\hline & Group & $\begin{array}{c}\text { Monthly } \\
\text { Income } \\
\text { (RMB) }\end{array}$ & N & $\begin{array}{c}\text { Subset for } \\
\text { alpha = 0.05 }\end{array}$ \\
\cline { 3 - 5 } & 1 & Below 2000 & 136 & \multicolumn{1}{|c|}{} \\
\hline Student-Newman- & 2 & $2000-3500$ & 37 & 4.0773 \\
Keuls & 3 & $3501-5000$ & 55 & 3.7604 \\
& 4 & Over 5000 & 15 & 3.8627 \\
& Sig. & & & 1.000 \\
\hline
\end{tabular}

Again One-way ANOVA was applied to compare the means of different education groups. The primitive result showed the respondents at lower education level got higher ethnocentrism score, which showed they were more ethnocentrism (see table V). At 5\% significant level, the combined P-value $=0.000$ showed the means of different subgroups were not statistically the same, but we couldn't make sure each groups was total different, so Multiple Comparisons was necessary. To check the differences between two groups, Multiple Comparisons were made and the P-value in the test of homogeneity of variances was 0.003. The Tamhane Multiple Comparisons result showed that education group1 had significant differences between all of the other three education groups, but group2, group3 and group4 had no differences among them (see table VI). This result showed that ethnocentrism had significant correlation with educational level and the respondents at high school or below degree were more ethnocentrism than those who have college or above degree. So hypothesis5 was accepted. But the respondents who had college degree, undergraduate degree, graduate degree or above showed similar ethnocentrism.

TABLE V. HOMOGENEOUS SUBSETS

\begin{tabular}{|c|c|c|c|c|c|c|}
\hline & \multirow[t]{2}{*}{ Group } & \multirow{2}{*}{$\begin{array}{c}\text { Educational } \\
\text { level }\end{array}$} & \multirow[t]{2}{*}{$\mathbf{N}$} & \multicolumn{3}{|c|}{ Subset for alpha $=\mathbf{0 . 0 5}$} \\
\hline & & & & 1 & 2 & 3 \\
\hline $\begin{array}{l}\text { Student- } \\
\text { Newman- } \\
\text { Keuls }\end{array}$ & $\begin{array}{c}3 \\
2 \\
1 \\
\text { Sig. }\end{array}$ & $\begin{array}{c}\text { Graduate degree } \\
\text { or above } \\
\text { Undergraduate degree } \\
\text { College degree } \\
\text { High school or below }\end{array}$ & $\begin{array}{c}6 \\
99 \\
53 \\
85\end{array}$ & 2.9300 & $\begin{array}{c}3.5782 \\
3.7789 \\
.529\end{array}$ & \begin{tabular}{|c}
3.7789 \\
4.3434 \\
.078
\end{tabular} \\
\hline
\end{tabular}

TABLE VI. MULTIPLE COMPARISONS ON EDUCATIONAL LEVEL

\begin{tabular}{|c|c|c|c|c|c|}
\hline & \begin{tabular}{|c|} 
(I) \\
Educational \\
level
\end{tabular} & $\begin{array}{c}(\mathbf{J}) \\
\text { Educationa } \\
\text { level }\end{array}$ & $1 \frac{\text { Mean }}{\text { Difference (I-J) }}$ & $\begin{array}{c}\text { Std. } \\
\text { Error }\end{array}$ & Sig. \\
\hline Tamhane & $\begin{array}{l}2 \\
3\end{array}$ & $\begin{array}{l}2 \\
3 \\
4 \\
1 \\
3 \\
4 \\
1 \\
2 \\
4 \\
1 \\
2 \\
3\end{array}$ & $\begin{array}{c}.56454^{*} \\
.76523^{*} \\
1.41341^{*} \\
-.56454^{*} \\
.20069 \\
.84887 \\
-.76523^{*} \\
-.20069 \\
.64818 \\
-1.41341^{*} \\
-.84887 \\
-.64818\end{array}$ & $\begin{array}{l}.17496 \\
.15512 \\
.27496 \\
.17496 \\
.14956 \\
.27186 \\
.15512 \\
.14956 \\
.25954 \\
.27496 \\
.27186 \\
.25954\end{array}$ & $\begin{array}{l}.009 \\
.000 \\
.005 \\
.009 \\
.701 \\
.086 \\
.000 \\
.701 \\
.237 \\
.005 \\
.086 \\
.237\end{array}$ \\
\hline
\end{tabular}

\section{CONCLUSIONS}

As international competition is intensifying, learning the characteristic of specific segments are more important than ever before. As the east coast region is becoming the main target market for MNC, the ethnocentrism research on the people living in the east coast region is significant. Many scholars examined CE measured with CESCALE among different countries and their antecedents and consequences, but the prior researches neglected the people living in countryside which restricted applicability of their research findings. This paper focuses on researching the correlation between the consumer ethnocentrism level of Chinese people and the demographic segmentation variables adopting samples from the whole Shandong province including cities and countryside.

The paper put forward five hypotheses and tested them accordingly. Hypothesis 1 tested the reliability and validity of CESCALE and found it was reliable and valid to use the CETSCALE to make further analysis. Hypothesis2 through Hypothesis5 tested the correlations between consumer ethnocentrism and gender, age, income and educational level respectively and the finding showed: different gender respondents had similar CE level. This conclusion was consistent with that of Imbert et al., but opposite to that of Klein and Ettenson. Ethnocentrism had a significant correlation with age, the respondents older than 35 years were more ethnocentrism than the respondents who were younger. This conclusion was consistent with that of Hsu and Nien. But the respondents who were older than 35 years old were similar ethnocentrism no matter they were younger or older. Ethnocentrism had no correlation with income, no matter how high their incomes were, they had similar ethnocentrism. Ethnocentrism had significant correlation with education and the respondents at lower educational levels were more ethnocentrism. This conclusion was consistent with that of Hsu and Nien, too. But respondents who had college degree and undergraduate degree showed similar ethnocentrism.

\section{LIMITATIONS AND IMPLICATIONS TO INTERNATIONAL MARKETERS}

Consumer ethnocentrism brings obstacles to international markers. Understanding the general CE level and adapt related communication strategies are significant But, international marketer should be clear that even the CE level is high or low in one country, it doesn't mean all people's consumer ethnocentrism is high or low. Different subgroups sometimes have significantly difference on $\mathrm{CE}$, So reasonably segment market and applying different communication strategies in China are crucial for international marketers. Though gender and income has no correlation with $\mathrm{CE}$, age and educational level do have correlation with CE in China. On the variables of age and educational level, the people in some groups do have differences but the differences between some groups were not significant. International marketers should be cautious on deciding segmentation variables and the application of these variables.

China is a huge country and economy conditions in the east region, middle region and west region are different. This paper sampled in only one east province which still neglect the other two regions. If segmentation can be made according to economical development level, and the samples could be from different provinces, the findings would be more reasonable and representative. 


\section{REFERENCES}

[1] Sun Shili, "An Analysis on the Conditions and Methods of Market Segmentation", International Journal of Business and Management $01 / 2009$.

[2] Boone and Kurtz, Comtemporary Marketing, 2013 edition, pp279

[3] Yoo, B. and Donthu, N. The Effect of Personal Cultural Orientation on Consumer Ethnocentrism: Evaluations and Behaviors of U.S. Consumers Toward Japanese Products, Journal of International Consumer Marketing, Vol. 18, pp. 7-44, 2005

[4] Nielsen, J. and Spence, M. A Test of the Stability of the CETSCALE, A Measure of Consumers' Ethnocentric Tendencies, Journal of Marketing Theory and Practice, Vol. 5, pp. 68-76, 1997

[5] Hsu, J.H. , Nien Hanpeng, Who are more ethnocentric? Examining consumer ethnocentrism in Chinese societies, Journal of Consumer Behaviour 7: pp436-447,2008.

[6] Bawa, Anupam. Consumer Ethnocentrism: CETSCALE Validation and Measurement of Extent. Vikalpa: The Journal for Decision Makers, Vol. 29, Issue 3, pp.43. 2004

[7] Shimp, T.A., \& Sharma, S. Consumer ethnocentrism: construction and validation of the CETSCALE, Journal of Marketing Research, 24 (3), pp.280-289,1987

[8] Durvasula, S., Andrews, J., and Netemeyer, R., A Cross-Cultural Comparison of Consumer Ethnocentrism in the United States and Russia, Journal of International Consumer Marketing, Vol. 9, pp. 73-93, 1997.

[9] Teo, P. C., Mohamad, O., \& Ramayah, T. Testing the dimensionality of Consumer Ethnocentrism Scale (CETSCALE) among a young Malaysian consumer market segment. African Journal of Business Management, 5(7), 2805-2816, 2011

[10] Shimp TA. Consumer ethnocentrism: the concept and a reliminary empirical test. Advances in Consumer Research, Vol. 11, 285-290. 1984

[11] Good L K and Huddleston P , "Ethnocentrism of Polish and Russian Consumers:Are Feelings and Intentions Related?", International Marketing Review, Vol. 12, No. 5, pp. 35-48, 1995

[12] Klein JG, Ettenson R. 1999- Consumer animosity and consumer ethnocentrism: an analysis of unique antecedents. Journal of International Consumer Marketing 11(4): 5-24.

[13] Philp K and Brown L (2003), "Does Consumer Ethnocentrism Impact on Australian Food Buying Behaviour?", Journal of New Business Ideas and Trends, Vol. 1, No. 2, pp. 24-43.

[14] Bandyopadhyay S and Muhammad M (1999), "Consumer Ethnocentrism in South Asia", retrieved from http://www.sbaer.uca.edu/research/sma/1999

[15] Imbert G, Jiddou K, Kumar S, Murillo A and Zhao P (2003), Analysis of Russian Values, Wayne State University, Detroit, USA, f rom http:// www.gerardimbert.com/files/mkt7995_research.pdf

[16] Bandyopadhyay S and Saevarsdottir K (2001), "Ethnocentrism in Icelandic Consumers and its Impact on the Evaluation of Imported Products", International Business Track,Decision Sciences Institute Annual Meeting, San Francisco, California.

[17] Nunnaly, J. (1978). Psychometric theory. New York: McGraw-Hill. 